\section{In Situ Effect of Titanium Tetrafluoride and Sodium Fluoride on Artificially Decayed Human Enamel}

Paula Cristina da Costa Alcântara, Adilis Kalina Alexandria, Ivete Pomarico

Ribeiro de Souza, Lucianne Cople Maia
Department of Pediatric Dentistry and Orthodontics, Dental School, UFRJ - Federal University of Rio de Janeiro, RJ, Brazil

Correspondence: Profa. Dra. Lucianne Cople Maia, Cidade Universitária - CCS, 21941-971 Rio de Janeiro, RJ, Brasil. Tel: +55-21-3988-9728. e-mail: rorefa@terra.com.br
This study compared in situ the application of 4\% titanium tetrafluoride $\left(\mathrm{TiF}_{4}\right)$ solution and $2 \%$ sodium fluoride (NaF) gel on artificial white-spot lesions in human enamel. A crossover, double-blind study using in situ caries models was carried out. Eleven volunteers used an intraoral appliance containing five demineralized human enamel blocks. The blocks $(n=170)$ were randomly divided according to treatment into the following groups: $\mathrm{TiF}_{4}(\mathrm{n}=55), \mathrm{NaF}(\mathrm{n}=55)$, positive control $(\mathrm{n}=55)$. A negative control group was composed of demineralized specimens $(n=5)$. The microhardness test was performed using a Knoop penetrator. Energy dispersive spectrometer (EDS) was used to analyze the concentration of titanium, calcium, phosphate and oxygen. The enamel microhardness at different depths for $\mathrm{TiF}_{4,} \mathrm{NaF}$ and positive control samples was not statistically different ( $p>0.05$ ). The samples from these three groups had statistically higher microhardness values than the negative control samples $(p<0.05)$. EDS analysis did not provide conclusive results about the penetration of titanium in the $\mathrm{TiF}_{4}$ samples. While in some fragments it had substantial penetration, in other fragments it only had superficial penetration. It was possible to conclude that, under in situ conditions, 4\% $\mathrm{TiF}_{4}$ solution and $2 \% \mathrm{NaF}$ gel were able to remineralize artificial white-spot lesions in human enamel. However, the magnitude of the remineralization did not differ between groups.
Key Words: dental caries, titanium, tooth remineralization, dental enamel.

\section{Introduction}

Fluoride may render the tooth surface harder, more resistant to demineralization, and more prone to remineralization $(1,2)$. Different topical fluoride agents are used for caries prevention. Among them, sodium fluoride has been proven able to reduce the solubility of the mineralized structure components $(3,4)$.

Titanium tetrafluoride emerged in this context, arousing interest due to its preventive and therapeutic properties despite not being a new product. Its cariostatic effect is obtained through both fluoride and titanium-rich cover layer formed on top of the enamel surface exposed to it, reducing its solubility levels and preventing cariogenic threat (5-7). Although titanium tetrafluoride has been under study since 1972 with very promising results (6), a definite protocol regulating its use has not yet been established yet. As result, the substance is not available in the market.

The null hypothesis of this study was that the application in situ of $4 \% \mathrm{TiF}_{4}$ solution and $2 \% \mathrm{NaF}$ gel is not able to remineralize artificial caries lesions in human enamel.

\section{Material and Methods Experimental Design}

This crossover, randomized and double-blind in situ study was carried out in accordance with the ethical standards of the committee responsible for human experimentation and with the Helsinki declaration, and was approved by institutional Research and Ethics Committee. Eleven volunteers participated in the study after signing an informed consent form. They were selected according to the criteria presented by Zero (8): good general health and no systemic disease; no use of drugs that modify salivary flow 60 days prior to the study; not having undergone radio/chemotherapy; presence of sufficient teeth to allow for the installation of intraoral palatal device; absence of severe tooth wear, caries activity, inadequate restorations, gingival recession or braces; no smoking habit, no bruxism.

The volunteers participated in all phases of the study. They were tested for salivary flow, buffer capacity, and Streptococcus mutans and Lactobacillus count before the start of the study. Additionally, the level of fluoride in the water supply of the participants' households was analyzed to enable the leveling off their participation ( $x=$ $0.415 \mathrm{mg} F / \mathrm{L}$ ). The volunteers were also warned both orally and in writing to: (i) avoid having fluoride applied to their teeth either by another professional or at home; (ii) use fluoride-free toothpaste while they were participating in the study; (iii) not to brush the intraoral appliances in the area of the tooth blocks; and (iv) to use their intraoral 
appliances all the time, except during meals.

The experimental model adopted consisted of three 15day phases, with a 7-day and a wash-out period between each phase. The volunteers wore acrylic palatal appliances containing human enamel blocks, and a $4.0 \mathrm{~mm}$ deep space was created in the acrylic appliance to fix the blocks. After caries lesion formation, the enamel blocks were placed in acrylic appliances for the experiment.

\section{Enamel Specimens Preparation}

The sample consisted of 50 unerupted third molars free of fractures, cracks, hypoplasia or hypocalcification, examined in a stereoscopic microscope (Leica, Buffalo Grove, IL, USA), magnified 40 times. The teeth where cleaned with curettes before sectioning to obtain the blocks and all dental roots were removed.

Four dental blocks measuring $4 \times 4 \mathrm{~mm}^{2}$ were obtained from each smooth surface of the teeth. The blocks were obtained using a double-sided diamond disc under constant refrigeration with a cutting machine (Buehler Ltd, Lake Bluff, IL, USA) and stored in $2 \%$ formaldehyde solution at pH 7.0 (Merck \& Co., Inc., Whitehouse Station, NJ, USA). Next, they were polished with 600- and 1200-grit silicon carbide paper, followed by $1 \mu \mathrm{m}$ diamond abrasive slurry and ultrasonically in MiliO water. The blocks were selected based on their baseline surface microhardness (SMH) (mean $341.59 \pm 34.15 \mathrm{~kg} / \mathrm{mm} 2)$. SMH was measured using a microhardness tester (HVS-1000; Time Group Inc., Haidian District, Beijing, China) with Knoop diamond under a $50 \mathrm{~g}$ load for $5 \mathrm{~s}$, by making 5 indentations spaced $100 \mu \mathrm{m}$ from each other at the center of enamel surface.

\section{Lesion Formation}

All tooth blocks received prophylaxis with fine pumice stone and water in a rubber cup, for $10 \mathrm{~s}$. They were washed with Mili0 water for $20 \mathrm{~s}$ and dried with compressed air from a triple syringe for $10 \mathrm{~s}$. The entire surface was coated with a layer of nail polish, except for a circular enamel area $(r=2 \mathrm{~mm})$ (9). The lesions were artificially formed according to Chevitarese et al. (10). After the artificial lesion were produced, five fragments were randomly separated and kept at $4{ }^{\circ} \mathrm{C}$ with $100 \%$ humidity during the experimental period of the study, to be used as negative controls.

\section{Intraoral Appliance and Preparation/Application of the Products}

Neutral sodium fluoride gel at a concentration of $2 \%$ (Topgel; Dentsply Ind. e Com., Ltda, Petrópolis, RJ, Brazil) was used. The $4 \%$ titanium tetrafluoride solution ( $\mathrm{pH} 1.2)$ was prepared by the Analytical Chemistry Department (Institute of Chemistry - UFRJ) the day before the experiment. Distilled water was added to $4.0 \mathrm{~g}$ of solid $\mathrm{TiF}_{4}$ (Aldrich Chemical Company Inc., St. Louis, MO, USA) with a final volume of $100 \mathrm{~mL}$

A small brush was used for 1 min application of fluoride products: $\mathrm{TiF}_{4}$ solution and $\mathrm{NaF}$ gel on the enamel window on the sample surfaces. The products were applied in the teeth in the intraoral appliance (Fig. 1), which was immediately put back in place. The volunteers were asked to put the appliance inside their oral cavity, keeping it there for half an hour without removing, in order to simulate the residual effect of fluoride in contact with saliva (11). In the control group, the devices were given to the volunteers but the samples did not receive any application of fluoride. Neither the volunteers nor the researcher knew which product was applied, for the sake of the double-blind

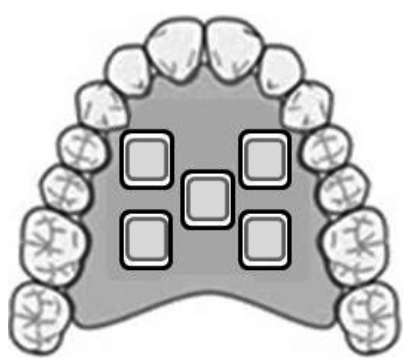

Figure 1. Schematic illustration of the intraoral appliance containing five demineralized human enamel blocks.

Table 1. Mean + SD of treatments and controls according to each depth analyzed (in Knoop hardness)

\begin{tabular}{lccccccc}
\hline \multirow{2}{*}{ Treatment } & \multicolumn{5}{c}{ Depths } \\
\cline { 2 - 7 } & $25 \mu \mathrm{m}$ & $50 \mu \mathrm{m}$ & $75 \mu \mathrm{m}$ & $100 \mu \mathrm{m}$ & $125 \mu \mathrm{m}$ & $175 \mu \mathrm{m}$ & $225 \mu \mathrm{m}$ \\
\hline $\mathrm{TiF}_{4}$ & $105.1 \pm 24.25^{\mathrm{A}}$ & $113.3 \pm 33.42^{\mathrm{A}}$ & $117.4 \pm 41.91^{\mathrm{A}}$ & $126.4 \pm 46.97^{\mathrm{A}}$ & $151.5 \pm 50.53^{\mathrm{A}}$ & $165.4 \pm 50.36^{\mathrm{A}}$ & $175.3 \pm 58.13^{\mathrm{A}}$ \\
$\mathrm{NaF}$ & $100.3 \pm 29.83^{\mathrm{A}}$ & $107.9 \pm 39.79^{\mathrm{A}}$ & $116.2 \pm 50.80^{\mathrm{A}}$ & $127.9 \pm 59.42^{\mathrm{A}}$ & $147.4 \pm 64.60^{\mathrm{A}}$ & $157.8 \pm 59.36^{\mathrm{A}}$ & $164.6 \pm 64.67^{\mathrm{A}}$ \\
Positive control & $99.0 \pm 30.73^{\mathrm{A}}$ & $105.8 \pm 37.88^{\mathrm{A}}$ & $116.2 \pm 45.61^{\mathrm{A}}$ & $126.0 \pm 46.32^{\mathrm{A}}$ & $147.8 \pm 59.74^{\mathrm{A}}$ & $156.8 \pm 64.72^{\mathrm{A}}$ & $161.7_{ \pm} 69.01^{\mathrm{A}}$ \\
Negative control & $58.8 \pm 7.80^{\mathrm{B}}$ & $60.0 \pm 17.40^{\mathrm{B}}$ & $51.0 \pm 19.00^{\mathrm{B}}$ & $49.8 \pm 15.85^{\mathrm{B}}$ & $60.4 \pm 15.49^{\mathrm{B}}$ & $79.5 \pm 23.64^{\mathrm{B}}$ & $94.8 \pm 24.22^{\mathrm{B}}$ \\
\hline
\end{tabular}

Different letters indicate statistically significant difference at 5\% significance level, one-way ANOVA test with 95\% confidence interval (lower limit 78.31; upper limit 214.39). 
nature of the study.

At the end of each phase, the blocks were removed for enamel mineral loss evaluation. The studied variables were: cross-sectional microhardness (CSMH), energy dispersive spectrometry (EDS) and scanning electron microscopy (SEM) analysis.

\section{Microhardness Evaluation}

At the end of the experimental period, the blocks of all groups (including positive control) were cut lengthways with a double-sided diamond disc, and then distributed in accordance with the carried out analyses. Half of each block was used for cross-sectional microhardness determination and the other half for EDS and SEM analysis.

The two halves were embedded in acrylic resin so that the cut section was exposed and gradually ground wet using 400-, 600- and 1200-grit silicon carbide papers (Buehler Ltd) and then polished with diamond paste with $3 \mu \mathrm{m}$ particles). CSMH test was performed using a Knoop penetrator (Micromet 2003; Buehler Ltd) with $25 \mathrm{~g}$ load for $5 \mathrm{~s}$. Three sequences of seven indentations spaced 50 $\mu \mathrm{m}$ from each other were made at depth of $25 \mu \mathrm{m}, 50 \mu \mathrm{m}$, $75 \mu \mathrm{m}, 100 \mu \mathrm{m}, 125 \mu \mathrm{m}, 175 \mu \mathrm{m}$, and $225 \mu \mathrm{m}$ from the outer enamel surface. The mean values were calculated at each distance and used to compare the groups.

\section{EDS and SEM Analyses}

The EDS analysis was made to assess the mineral content of enamel. Identifying the chemical elements in surface enamel, it was possible to detect the elements in the samples from boron and up $(Z \geq 5)$. Thus, the analyzed elements were: titanium ( $\mathrm{Ti})$, fluoride $(\mathrm{F})$, oxygen ( 0 ), carbon (C), sodium ( $\mathrm{Na}$ ), calcium (Ca) and phosphorus (P). This analysis was performed with link to automatic image analyzer system Kontron. A punctual analysis was carried out for three different depths: $25 \mu \mathrm{m}, 100 \mu \mathrm{m}$ and $225 \mu \mathrm{m}$, and the results were analyzed descriptively and represented by the means of measured values. The scanning electron microscope (JEOL-JSM - 5800LV; Tachikawa, Tokyo, Japan) at $20 \mathrm{kV}$ was used for morphological evaluation of the subsurfaces. Before the analyses, the samples were fixed in stubs with enamel subsurface turned upward, and sputter-coated with a 20 to $30 \mathrm{~nm}$ gold layer. Only the top third of the carious lesions were observed in the SEM, with magnifications of $200 x$ and $1000 x$.

\section{Statistical Analysis}

The normal distribution of data was checked for all the tested variables, using the Shapiro Wilk test. Differences in CSMH among treatments $\left(\mathrm{TiF}_{4}, \mathrm{NaF}\right.$, negative and positive control) were tested using one-way ANOVA and Tukey test
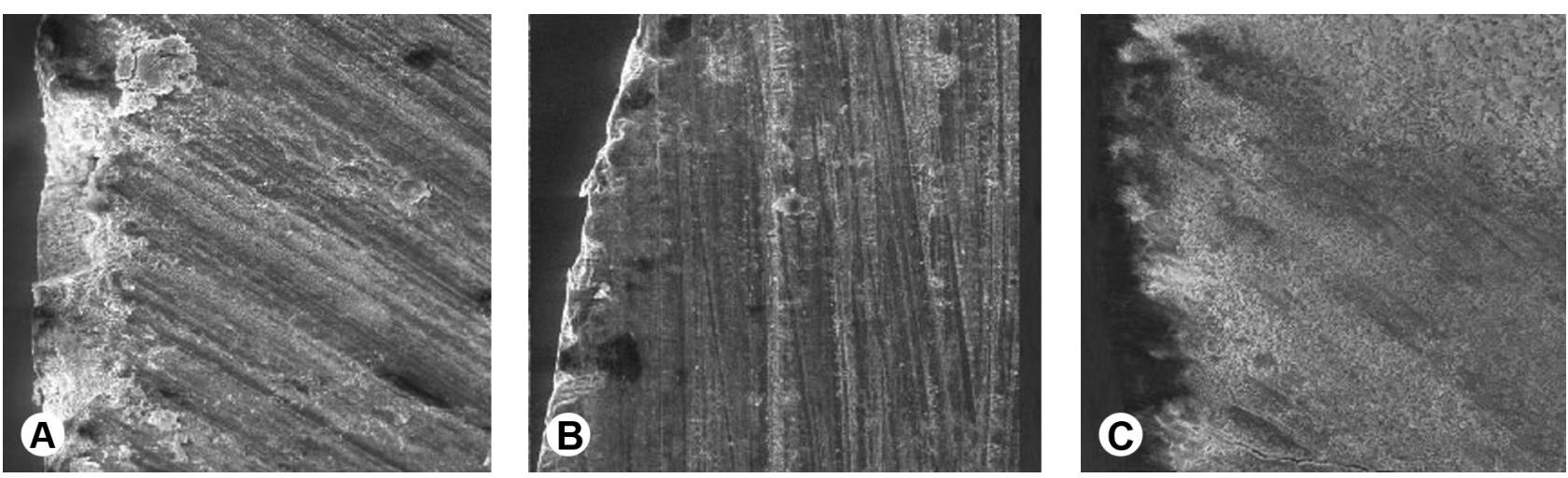

Figure 2. SEM micrographs of the in situ groups. A: Positive control group. B: Group treated with NaF. C: Group treated with TiF . $_{4}$

Table 2. Mean values of the elements of the 3 groups of enamel blocks (EDS analysis)

\begin{tabular}{lcccccccccccc}
\hline & \multicolumn{3}{c}{$\begin{array}{c}\text { Titanium } \\
\text { (\% atomic number) }\end{array}$} & \multicolumn{2}{c}{$\begin{array}{c}\text { Calcium } \\
\text { (\% atomic number) }\end{array}$} & \multicolumn{2}{c}{$\begin{array}{c}\text { Phosphorous Means } \\
\text { (\% atomic number) }\end{array}$} & \multicolumn{3}{c}{$\begin{array}{c}\text { Oxygen } \\
\text { (\% atomic number) }\end{array}$} \\
\hline Treatments/ Depth & $25 \mu \mathrm{m}$ & $100 \mu \mathrm{m}$ & $225 \mu \mathrm{m}$ & $25 \mu \mathrm{m}$ & $100 \mu \mathrm{m}$ & $225 \mu \mathrm{m}$ & $25 \mu \mathrm{m}$ & $100 \mu \mathrm{m}$ & $225 \mu \mathrm{m}$ & $25 \mu \mathrm{m}$ & $100 \mu \mathrm{m}$ & $225 \mu \mathrm{m}$ \\
$\mathrm{TiF}_{4}$ & 0.84 & 0.72 & $0.41^{*}$ & 31.52 & 37.11 & 35.43 & 16.81 & 14.95 & 16.67 & 59.88 & 59.09 & 59.66 \\
$\mathrm{NaF}$ & - & - & - & 23.25 & 26.75 & 24.64 & 12.26 & 11.04 & 12.76 & 59.16 & 58.20 & 57.85 \\
$\mathrm{Control}+$ & - & - & - & 21.89 & 24.34 & 22.74 & 10.80 & 9.91 & 10.64 & 58.66 & 58.08 & 58.57 \\
\hline
\end{tabular}

*inconclusive data. 
(post-hoc test). SPSS software (version 17.0) was used for the statistical analysis with a significance level set at 5\%. SEM and EDS results were analyzed descriptively.

\section{Results}

\section{Microhardness Results}

The mean values for the three indentations made at the seven depths for each fragment were analyzed. A direct relationship between microhardness and depth was observed. There were no statistically significant differences in microhardness at the various layers among $\mathrm{TiF}_{4} \mathrm{NaF}$ and the positive control groups ( $p>0.05$ ) as shown in Table 1.

The negative control group presented lower microhardness values than the $\mathrm{TiF}_{4}$ and $\mathrm{NaF}$ samples and the positive control group in all layers $(\mathrm{p}<0.05)$. As shown in Table 1, those differences were considered statistically significant since the results were outside the limits of the $95 \%$ confidence interval.

\section{EDS and SEM Results}

The EDS analyses (Table 2) indicated that titanium was able to substantially penetrate some fragments whereas other fragments were only superficially penetrated. The mean level of calcium and phosphorous for the $\mathrm{TiF}_{4}$ sample at all layers was higher than the ones found for the $\mathrm{NaF}$ sample and the control group. The same was not true for oxygen; all three groups had similar levels of oxygen in all layers. However, the differences of mean concentration for all substances among the different groups were so small that no definite conclusions could be achieved.

In the SEM images of the positive control group (Fig. $2 \mathrm{~A})$, the porous and heterogeneous pattern of enamel was observed too. The group treated with $\mathrm{TiF}_{4}$ also showed more heterogeneity on enamel (Fig. $2 \mathrm{C}$ ), if compared with the $\mathrm{NaF}$ group (Fig. 2B).

\section{Discussion}

This experiment sought to determine the capacity of a single dose of $4 \%$ titanium tetrafluoride to promote remineralization of artificially damaged human enamel. To strengthen our conclusions, the performance of $\mathrm{TiF}_{4}$ was compared with that of a material that has long been its substitute in the market: $2 \%$ sodium fluoride.

The literature provides little information on the therapeutic effect of titanium tetrafluoride $(7,12-$ 14). Clarkson and Wefel (13) evaluated in vitro the remineralization of carious lesions in the enamel comparing $\mathrm{TiF}_{4}$ and APF (acidulated phosphate fluoride). They concluded that the former yielded better results than the latter. However, this fact was not observed in the present study, since $\mathrm{TiF}_{4}$ and $\mathrm{NaF}$ behaved in a similar way in terms of transversal microhardness values, showing no statistically significant difference between them or in relation to the positive control group.

Castro et al. (12) evaluated in situ the preventive and therapeutic effects of $\mathrm{TiF}_{4}$ on the occlusal surface of permanent molars. They concluded that $\mathrm{TiF}_{4}$ had actually prevented carious lesions, but it was not possible to observe its therapeutic effect. This study corroborates the present study since the results for $\mathrm{TiF}_{4} \mathrm{NaF}$ and positive control group had very similar microhardness values, which characterizes the incapacity of such fluoride composites to remineralize completely the enamel according to the above-mentioned methodology. A new titanium fluoride derivative (SATIF, Sanofi-Aventis, Paris, France) was tested in a pH-cycling study showing that re-applying the treatment solutions resulted in a higher degree of protection.

To better contextualize these findings it is important a deeper discussion about remineralization. According Hicks et al. (15), this phenomenon occurs when the demineralized enamel is exposed to saliva supersaturated by phosphates and calcium. The saliva promotes the restart of the mineralization process, helping the lost calcium and phosphate to be incorporated again into the enamel.

Based on this definition, it is possible to state that the three experimental groups in the present study had a better performance in comparison to the negative control group. Considering that complete remineralization resulting from professional application of topical fluoride in both forms ( $\mathrm{TiF}_{4}$ and $\mathrm{NaF}$ ) could not be observed in the present study, the similarity between the results may be attributed to the saliva, which is the main agent responsible for the continuous ion exchange and consequent maturation of the enamel (16).

Our findings highlight the fact that the fluoridebased products herein applied should have stabilized the demineralization instead of increasing the remineralization. This may be explained by the action of fluoride on the kinetics of the carious process (17). It is well known that fluoride ions, when incorporated into or absorbed by hydroxyapatite crystal, become more resistant to acid dissolution (18).

Another aspect worth discussing is how $\mathrm{TiF}_{4}$ works. When applied to a dental structure, $\mathrm{TiF}_{4}$ reacts with the oxygen forming a layer of titanium dioxide on the surface. This new layer acts as a physical barrier preventing the penetration of acids released by the bacteria $(1,19)$. However, EDS shows that such a layer is not homogenous because some areas of the enamel are still exposed to bacterial acid production. The morphology of the enamel may explain the breaches in the titanium dioxide layer. The enamel inorganic content is formed by phosphate crystals and hydroxyapatite, whose concentrations change depending on the region and the involved teeth $(10,20)$. 
As for the SEM analyses, it was observed that $\mathrm{TiF}_{4}$ modifies the enamel structure, if compared to the $\mathrm{NaF}$ group. It may be suggested that this fact may be the result of an extremely acid $\mathrm{pH}$ in the substance under study. Although there has been destruction, the enamel crosssectional microhardness increased in this group. Regarding the titanium penetration observed in EDS, our results are in accordance with those of Chevitarese et al. (10) who found smaller titanium penetration in the carious enamel. As the present study found low levels of titanium penetration, it may be concluded that since the carious enamel contains a smaller quantity of water and carbonate - oxygen sources (18), the fusion between titanium and the oxygen in the dental structure is impaired, thus causing a decrease in the levels of titanium dioxide formation.

Another aspect that may be observed in relation to the EDS results is that, based on the amounts of calcium, phosphorus and oxygen, the mineral contents of the three groups are similar, a fact that is in agreement with the obtained microhardness values.

In conclusion, the present study showed that although the products have been able to remineralize artificial caries lesions in human enamel in situ, the remineralization was similar to that produced by saliva. Therefore, it is suggested that new therapeutic schemes should be tested in order to investigate the likely interference of $\mathrm{TiF}_{4}$ in promoting remineralization of artificially produced carious enamel.

\section{Resumo}

Este estudo comparou in situ a aplicação de uma solução de tetrafluoreto de titânio (TiF4) a 4\% e um gel de fluoreto de sódio (NaF) sobre lesões de mancha branca artificiais em esmalte dentário humano. Foi realizado um estudo cruzado, duplo-cego utilizando um modelo in situ de cárie. Onze voluntários usaram um aparelho intraoral contendo cinco blocos de esmalte humanos desmineralizados. Os blocos $(n=170)$ foram divididos aleatoriamente de acordo com o tratamento nos seguintes grupos: TiF4 $(n=55), \mathrm{NaF}(n=55)$, controle positivo $(n=55)$. Um grupo controle negativo foi composto de espécimes desmineralizados $(n=5)$. 0 teste de microdureza foi realizado utilizando um penetrador Knoop. Espectrômetro de energia dispersiva (EDS) foi utilizado para analisar a concentração de titânio, cálcio, fosfato e oxigênio. A microdureza do esmalte em diferentes profundidades para as amostras dos grupos TiF4, $\mathrm{NaF}$ e controle positivo não diferiram estatisticamente $(p>0,05)$. As amostras destes três grupos apresentaram valores de microdureza estatisticamente maiores do que as amostras do controle negativo $(p<0,05)$. A análise EDS não forneceu resultados conclusivos sobre a penetração de titânio nas amostras de TiF4. Apesar de apresentar, em alguns fragmentos, uma penetração substancial, em outros fragmentos apresentou apenas penetração superficial. Foi possivel concluir que, sob as condições do estudo in situ, a solução de TiF4 a 4\% e o gel de $\mathrm{NaF}$ a $2 \%$ foram capazes de remineralizar lesões de mancha branca em esmalte humano. No entanto, a magnitude da remineralização não diferiu entre os grupos.

\section{Acknowledgements}

We are grateful to Dr. Paulo Bechara from the Institute of Chemistry- UFRJ. retention of fluoride after a brief application of $\mathrm{TiF}_{4}$ to dentin. Acta Odontol Scand 1989;47:65-68.

2. Cury JA, Francisco SB, Del Bel Cury AA, Tabchoury CP. In situ study of sucrose exposure, mutans streptococci in dental plaque and dental caries. Braz Dent J 2001;12:101-104.

3. Seppa L. Effects of a sodium fluoride solution and a varnish with different fluoride concentrations on enamel remineralization in vitro. Scand J Dent Res 1988;96:304-309.

4. Moi GP, Tenuta LM, Cury JA. Anticaries potential of a fluoride mouthrinse evaluated in vitro by validated protocols. Braz Dent J 2008;19:91-96.

5. Mundorff SA, Little MF, Bibby BG. Enamel dissolution. II. Action of titanium tetrafluoride. J Dent Res 1972;51:1567-1571.

6. Shrestha BM, Mundorff SA, Bibby BG. Enamel dissolution. I. Effects of various agents and titanium tetrafluoride. J Dent Res 1972;51:15611566.

7. Nassur C, Alexandria AK, Pomarico L, de Sousa VP, Cabral LM, Maia LC. Characterization of a new $\mathrm{TiF}_{4}$ and beta-cyclodextrin inclusion complex and its in vitro evaluation on inhibiting enamel demineralization. Arch Oral Biol 2013;58:239-247.

8. Zero DT. In situ caries models. Adv Dent Res 1995;9:214-230.

9. White DJ. Reactivity of fluoride dentifrices with artificial caries. I. Effects on early lesions: F uptake, surface hardening and remineralization. Caries Res 1987;21:126-140.

10. Chevitarese AB, Chevitarese O, Chevitarese LM, Dutra PB. Titanium penetration in human enamel after $\mathrm{TiF}_{4}$ application. J Clin Pediatr Dent 2004;28:253-256.

11. Cury JA, Rebelo MA, Del Bel Cury AA, Derbyshire MT, Tabchoury CP. Biochemical composition and cariogenicity of dental plaque formed in the presence of sucrose or glucose and fructose. Caries Res 2000;34:491-497.

12. Castro R, Chevitarese 0 , Souza IPR. The application of in vitro models to research on demineralization and remineralization of the teeth. Fluoride 2003;36:252-262.

13. Clarkson $B$, Wefel J. Titanium and fluoride concentrations in titanium tetrafluoride and APF treated enamel. J Dent Res 1979;58:600-603.

14. Wiegand $A$, Magalhaes $A C$, Attin $T$. Is titanium tetrafluoride $\left(\mathrm{TiF}_{4}\right)$ effective to prevent carious and erosive lesions? A review of the literature. Oral Health Prev Dent 2010;8:159-164.

15. Hicks J, Garcia-Godoy F, Flaitz C. Biological factors in dental caries: role of remineralization and fluoride in the dynamic process of demineralization and remineralization (part 3). J Clin Pediatr Dent 2004;28:203-214.

16. Barbakow F, Imfeld T, Lutz F. Enamel remineralization: how to explain it to patients. Quintessence Int 1991;22:341-347.

17. Featherstone JD. Dental caries: a dynamic disease process. Aust Dent J 2008;53:286-291.

18. ten Cate JM. Current concepts on the theories of the mechanism of action of fluoride. Acta Odontol Scand 1999;57:325-329.

19. Buyukyilmaz T, Ogaard B, Duschner H, Ruben J, Arends J. The cariespreventive effect of titanium tetrafluoride on root surfaces in situ as evaluated by microradiography and confocal laser scanning microscopy. Adv Dent Res 1997;11:448-452.

20. Buyukyilmaz $T$, Ogaard B, Rolla G. The resistance of titanium tetrafluoride-treated human enamel to strong hydrochloric acid. Eur J Oral Sci 1997;105:473-477.

\section{References}

1. Skartveit $L$, Tveit AB, Klinge B, Totdal B, Selvig KA. In vivo uptake and

Received September 2, 2013 Accepted February 12, 2014 